\title{
The Impact of Innovation and Information Technology on Greenhouse Gas Emissions: A Case of the Visegrád Countries
}

\author{
Radosław Miśkiewicz (D)
}

Citation: Miśkiewicz, Radosław. 2021. The Impact of Innovation and Information Technology on Greenhouse Gas Emissions: A Case of the Visegrád Countries. Journal of

Risk and Financial Management 14: 59. https://doi.org/10.3390/jrfm14020059

Academic Editor: Michael McAleer

Received: 16 December 2020

Accepted: 20 January 2021

Published: 2 February 2021

Publisher's Note: MDPI stays neutral with regard to jurisdictional claims in published maps and institutional affiliations.

Copyright: (C) 2021 by the author Licensee MDPI, Basel, Switzerland. This article is an open access article distributed under the terms and conditions of the Creative Commons Attribution (CC BY) license (https:// creativecommons.org/licenses/by/ $4.0 /)$
Faculty of Organisation and Management, Silesian University of Technology, 44-100 Gliwice, Poland; radoslaw.miskiewicz@polsl.pl

\begin{abstract}
The rapid growth of negative consequences from climate changes provokes divergent effects in all economic sectors. The experts proved that a core catalyst which bootstrapped the climate changes was greenhouse gas emission. This has led to a range of social, economic, and ecological issues. Such issues could be solved by extending innovation and information technology. This paper aimed to check the hypothesis that innovation and information technology allowed for a reduction of greenhouse gas emissions. The author used such methodology as OLS, fully modified OLS (FMOLS), dynamic OLS (DMOLS), Dicky-Fuller and Phillips-Perron tests. The research is informed by the report of the World Economic Forum, World Data Bank, Eurostat for the Visegrád countries (Hungary, Poland, Check Republic, Slovakia) for the period of 2000-2019. The findings were confirmed in models without control variables, and an increase of $1 \%$ of patents led to reducing greenhouse gas (GHG) emissions by $0.28 \%$ for Poland, $0.28 \%$ for Hungary, $0.38 \%$ for the Slovak Republic and $0.46 \%$ for the Czech Republic. At the same time, for the models with control variables, only Hungary experienced a statistically significant impact. There, an increase of patents by $1 \%$ led to reduction of GHG emissions by $0.22 \%$. The variable R\&D expenditure was statistically significant for all countries and all types of models (with and without control variables). The increase of R\&D expenditure provoked a decline of GHG emissions by $0.29 \%$ (without control variables) and $0.11 \%$ (with control variables) for Poland, by $0.26 \%$ (without control variables) and $0.41 \%$ (with control variables) for Hungary, by $0.3 \%$ (without control variables) and $0.23 \%$ (with control variables) for the Slovak Republic and by $0.54 \%$ (without control variables) and $0.38 \%$ (with control variables) for the Czech Republic.
\end{abstract}

Keywords: emission; carbon dioxide; Internet; climate change

\section{Introduction}

Climate changes are global issues which provoke irreversible negative consequences in all sectors. The core catalysts of climate changes include an increasing volume of greenhouse gas emissions. World experts have been trying to overcome these issues through implementing the principles of sustainable development. The European Commission has accepted the Green Deal Policy under the updated Cohesion policy. The Green Deal Policy aims to decarbonize the economy by reducing greenhouse gas emission (GHG emission) by implementing smart technologies, green energy and extending principles of the green economy. Further, the European Commission has already developed incentive mechanisms to urge the coal region to achieve the indicated goals.

Scientists around the world have been trying to empirically confirm the impact of a huge range of variables on reducing greenhouse gas emission with the goal of finding effective solutions and relevant instruments which guarantee a positive effect. Thus, the authors Lange et al. (2020) tried to confirm the hypothesis that information and communication technologies (ICT) allowed a decline in energy demand. At the same time, they highlighted that digitalization led to increasing energy consumption. In this case, the scientists received a vice versa circle. Nair et al. (2020) confirmed that expenditure on 
R\&D and ICT infrastructure had a statistically significant positive impact on long-term economic growth. For a calculation, they used a dataset for OECD countries and the GMM approach. Nair et al. (2020) used telephone landlines, mobile phones, composite index of ICT infrastructure, internet users, internet servers and fixed broadband as the variables for estimating ICT. The same conclusion was obtained by Majeed and Ayub (2018). These authors used additional indicators to explain the ICT, such as an e-government index, telecommunication and online service.

Asongu and Odhiambo (2019) used the GMM approach to confirm that FDI generates an increasing level of the mobile and internet penetration. In addition, they used mobile and internet penetration as the core determinants of ICT development in a country. On the contrary, the scientists Chimbo (2020) and Raheem et al. (2020) proved that ICT has a negative impact on GDP and $\mathrm{CO}_{2}$ emissions. Further, Chimbo (2020) confirmed that, for African countries, spreading of ICT led to an increase of energy consumption. Chimbo (2020) and Raheem et al. (2020) estimated ICT by the following variables: telephone landlines, mobile phone penetration and internet penetration. Siddiqui and Singh (2020) estimated a link between the ICT penetration and the economic growth using the BreuschPagan Lagrange Multiplier (LM) test, Pooled OLS, and fully modified OLS (FMOLS). The ICT penetration was estimated by principal component analysis (PCA) through the following indicators: individuals using the Internet (as a percentage of population); fixed broadband, telephone, and mobile subscriptions (per 100 people); ICT trade in goods.

Arshad et al. (2020) checked the impact of ICT, trade, economic growth, financial development and energy consumption on carbon dioxide emissions using the Unit root tests, DOLS and GM-FMOLS. In this case, they used the sum of the fixed telephone and mobile subscription data per 100 people as the variables for evaluating ICT. Tsaurai (2020) showed that ICT has an impact on financial development for African countries. Tsaurai (2020) estimated ICT by share of the total population using the Internet. Many scientists (Bogachov et al. 2020; Dzwigol et al. 2020; Kuzior et al. 2019; Kwilinski 2018a; Kwilinski et al. 2019; Kwilinski and Kuzior 2020; Miskiewicz 2019a, 2019b, 2020a; Miśkiewicz and Wolniak 2020) showed that implementing artificial intelligence allowed boosting the achievement of sustainable development goals.

Dkhili (2018) confirmed the link between environmental performance and the country's development using GDP as a key indicator of economic growth. Pajak et al. (2017), Miskiewicz (2018), Kwilinski et al. (2020a, 2020b), Dzwigoł et al. (2019) and Saługa et al. (2020) analysed energy security as the key indicator of the economic growth.

Vasylieva et al. (2019) and Bilan et al. (2019) confirmed that the spread of renewable energy reduces GHG emissions. They also proved that a decline of corruption allowed a reduction in air pollutions. Khan et al. (2020) proved that ICT in green infrastructure allowed cutting GHG emissions. The summary of the approaches to estimate the link among ICT, economic growth and GHG emissions is showed in Table 1. 
Table 1. The Approaches to Estimating the Link among ICT, Economic Growth and GHG Emissions (Source: developed by the author).

\begin{tabular}{|c|c|c|c|c|}
\hline Author & Period, Country & Methodology & Variable & Findings \\
\hline \multicolumn{5}{|c|}{ ICT and Economic growth } \\
\hline Nair et al. (2020) & 1961-2018, OECD & GMM approach & $\begin{array}{l}\text { RDE, RDR, RDT, TEL, MOB, INU, INS, } \\
\text { FIB, CIC, PEG }\end{array}$ & $\begin{array}{l}\text { RDE, RDR, and RDT positive impact on TEL, MOB, } \\
\text { INU, INS, FIB, CIC and PEG }\end{array}$ \\
\hline Majeed and Ayub (2018) & 1980-2015, 149 countries & $\begin{array}{l}\text { OLS, Pooled OLS, 2SLS, GMM approach, } \\
\text { PCA }\end{array}$ & $\begin{array}{c}\text { TEL, INU, INS, FIB, T, OS, EG, GDP, L, } \\
\text { PC, H, I, E }\end{array}$ & $\begin{array}{l}\text { INU, TEL, INS, FIB, T, OS, EG } \\
\text { Positive impact on GDP }\end{array}$ \\
\hline Asongu and Odhiambo (2019) & 1980-2014, Sub-Saharan Africa & GMM approach & $\begin{array}{l}\text { GDP, GDP per capita, real GDP MP, IP, } \\
\text { FDI }\end{array}$ & $\begin{array}{l}\text { FDI generate the increasing MP and IP, MP and IP } \\
\text { positive impact on GDP, GDP per capita, real GDP }\end{array}$ \\
\hline Siddiqui and Singh (2020) & $\begin{array}{l}\text { 2001-2018, developed and } \\
\text { developing countries }\end{array}$ & $\begin{array}{l}\text { Breusch-Pagan Lagrange Multiplier } \\
\text { (LM) test, Pooled OLS, FMOLS }\end{array}$ & TR, FDI, ICTp, FD, GDP per capita & ICT positive impact on TR and GDP per capita \\
\hline \multicolumn{5}{|c|}{ ICT, Economic growth and GHG emissions } \\
\hline Raheem et al. (2020) & 1990-2014, G7 countries & PMG & TEL, MOB, P, TR, $\mathrm{CO}_{2}$, URB, FD, GDP & $\begin{array}{l}\text { ICT positive long-run effect on } \mathrm{CO}_{2} \text {, ICT and FD } \\
\text { negative impact on GDP in long-term }\end{array}$ \\
\hline Chimbo (2020) & 2001-2015, African countries & $\begin{array}{l}\text { Fixed effects, random effects, pooled } \\
\text { OLS and the dynamic GMM }\end{array}$ & ICT, E, GDP, HD, P, FDI & $\begin{array}{l}\text { ICT and E negative impact on GDP, } \\
\text { FDI, } P \text {, HD positive impact on GDP }\end{array}$ \\
\hline Arshad et al. (2020) & $\begin{array}{l}\text { 1990-2014, South and Southeast } \\
\text { Asian }\end{array}$ & Unit root tests, DOLS and GM-FMOLS & ICT, TR, GDP per capita, $\mathrm{FD}, \mathrm{U}, \mathrm{CO}_{2}$ & $\begin{array}{l}\text { FD and ICT deteriorated the environment quality, } \\
\text { bidirectional causality between } \mathrm{CO}_{2} \text { and E, } \\
\text { unidirectional causality from TR, GDP per capita, FD, } \\
\text { and ICT to } \mathrm{CO}_{2}\end{array}$ \\
\hline Tsaurai (2020) & 2001-2015, Africa & Dynamic GMM & $\begin{array}{l}\text { ICT, HD, P, E, GDP per capita, U, TR, } \\
\text { FDI, IN }\end{array}$ & ICT and E significant impact on FD (board money) \\
\hline Bilan et al. (2019) & 1995-2015, EU . & FMOLS, DOLS, VECM & RESs, $\mathrm{CO}_{2}$, GDP, $\mathrm{L}$ and $\mathrm{K}$ & linking RESs, $\mathrm{CO}_{2}, \mathrm{~L}, \mathrm{~K}$ and GDP \\
\hline Vasylieva et al. (2019) & 2000-2016, EU and Ukraine & Panel unit root tests, FMOLS, DOLS & RE, GHG, GDP and CC & Increasing RE decline GHG, CC decline \\
\hline Khan et al. (2020) & 1990-2017, 91 countries & PCA, PCSE & $\mathrm{ICT}, \mathrm{CO}_{2}$ & ICT reduce $\mathrm{CO}_{2}$ \\
\hline
\end{tabular}


Lyulyov and Pimonenko (2017) analysed the investment as a drive for innovation development using the Lotka-Volterra synergy model. Kendiukhov and Tvaronavičienè (2017) proved that innovation development boosts achievement of sustainable economic growth.

The results of the analysis showed that the researchers used different approaches to estimating the relation among ICT, economic growth and GHG emissions. Scientists used several approaches to evaluating ICT. Mostly, scientists explained ICT by means of the following indicator: individual users of Internet (as a \% of the population). At the same time, the indicator GDP per capital was mostly used to explain the countries' economic growth.

Considering the findings, the scientists confirmed the positive impact of ICT on the country's economic growth and ecological development. However, the range of the papers proved that developing ICT increased energy consumption and GDP, which provoked the rapid growth of GHG emissions. It should be noted that the conclusions mostly relate to the sample of the countries as the object of the research. Considering the EKC hypothesis, economic growth is the main force to improve the quality of life and reduce the negative impact on the environment (Kuznets 1955). Developed countries have more options to finance innovations and informational technologies development. Thus, the core hypothesis of the paper is that economic growth influences GHG emissions which could be reduced by implementing innovations and informational technologies.

\section{Materials and Methods}

Among the EU countries, Poland and the Czech Republic were among the top 10 polluters with GHG emissions. In 2018, Poland produced 415,858.2 thousand tons or 9\% of the GHG emissions of the EU-28. Additionally, Poland and the Czech Republic are the European regions with coal-dependent economies. Considering the Green Deal Policy, the EU is aiming to become the climate-neutral in 2050, supporting the most affected regions (such as Poland and the Czech Republic) will be necessary. In this case, considering the above-mentioned tendencies on extending the innovations and informational technologies with the purpose of reducing the negative consequences of climate changes is topical and important.

In the framework of this research, the following EU countries were chosen: Hungary, Czech Republic, Slovak Republic and Poland for the period of 2000-2019. The Visegrád countries joined the EU in 2004 and have common historical roots. The core indicators of the Visegrád countries selected for analysis are showed in Table 2.

Table 2. Explanation of the variables (Source: developed by the author).

\begin{tabular}{ccc}
\hline Variables & Abbreviations & Source \\
\hline Greenhouse gas emission & GHG & Eurostat \\
Research and development expenditure (\% of GDP) & RD & World Data Bank \\
Patent applications, residents & PA & World Data Bank \\
Labour force participation rate, total (\% of total & HC & World Data Bank \\
population ages 15-64) (modelled ILO estimate) & Inv & World Data Bank \\
Individuals using the Internet (\% of the population) &
\end{tabular}

The GDP and labour force participation rate were used to explain the economic growth of each country. The innovation and information technologies were explained by indicators as follows: individuals using the Internet, research and development expenditure, and patent applications. GHG emissions were a dependent variable which, besides $\mathrm{CO}_{2}$, combined all types of contaminants.

The findings proved that production activities provoked degradation of the environment and imbalances of the ecosystem. Traditionally, scientists (including Kuznets 1955; 
Bilan et al. 2019; Dementyev and Kwilinski 2020; Kwilinski et al. 2020b; Vasylieva et al. 2019; Khan et al. 2020) described such a relationship using the quadratic function:

$$
E=F\left(Y, Y^{2}, Z\right)
$$

where $E$ is environmental pollution, $Y$ is output and $Z$ are the explanatory variables.

The core sources of environmental degradation are economic sectors which require additional investments for innovation and information technology with the purpose of minimizing the destructive impact on the environment. Considering the analysis of various approaches (Arshad et al. 2020; Bilan et al. 2019; Chygryn et al. 2020; Kharazishvili et al. 2020; Kwilinski 2018b; Majeed and Ayub 2018; Mazurkiewicz and Lis 2018; Miskiewicz 2020b; Zahorskyi et al. 2019; Vasylieva et al. 2019) to estimate the relationships between economic growth and innovation development, information technologies, GHG emissions, scientists mostly use OLS for each country, as well as FMOLS and DMOLS for all selected countries. In this case, to study the impact of innovation and information technology on greenhouse gas emission, the following type of models were used:

- $\quad$ for each country:

$$
\mathrm{GHG}_{t}=\alpha_{0}+\alpha_{1} G D P_{t}+\alpha_{2} R D_{t}+\alpha_{3} P A_{t}+\alpha_{4} I n v_{t}+\alpha_{5} H C_{t}+e_{t}
$$

- $\quad$ for all selected countries:

$$
\mathrm{GHG}_{i t}=\beta_{0}+\beta_{1} G D P_{i t}+\beta_{2} R D_{t}+\beta_{3} P A_{t}+\beta_{4} I n v_{i t}+\beta_{5} H C_{t}+e_{i t}
$$

where $\alpha_{0} \ldots \alpha_{5}, \beta_{0} \ldots \beta_{5}$ are estimated parameters of the model, $i$ symbolizes the countries, $t$ is time and $e_{i t}, e_{t}$ are error terms.

All variables of models (2) and (3) were in logarithm with the purpose to eliminate the heteroskedasticity. In addition, stationary time series were used to calculate the unknown parameters of models (2) and (3). The analysis results confirmed that widespread tests for checking the time series stationarity were Dicky-Fuller and Phillips-Perron tests (Akimova et al. 2017; Raheem et al. 2020; Chimbo 2020; Arshad et al. 2020). Thus, the main stage of estimating the impact of innovation and information technology on greenhouse gas emission were:

(1) Stationary testing at the level and first differences of time series of the model (2) using the unit root tests, the ADF-statistic and Phillips-Perron tests. Thus, the ADF technique was based on the following equation:

$$
y_{t}=c+\beta t+\alpha y_{t-1}+\sum_{j=1}^{p} \varphi_{i j} Y_{t-1}+\varepsilon_{i, t-1}
$$

where $y$ takes the meaning of each parameter of Equation (2); $\mathrm{y}_{\mathrm{t}-1}$ is a lag 1 of time series; $\mathrm{Y}_{\mathrm{t}-1}$ is the first Difference of the series at the time $(\mathrm{t}-1) ; \rho_{\mathrm{i}}=0$ for all $\mathrm{i}$ - the null hypothesis; $\rho_{\mathrm{i}}<0$ for at least one $\mathrm{i}$ is an alternative hypothesis non-existent of a unit root.

(2) Checking of a long-term relation between the series of Equations (2) and (3) using OLS for each country and the Fully Modified OLS (FMOLS), Dynamic OLS (DOLS) panel cointegration techniques for all selected countries.

\section{Results}

At the first stage of the research, descriptive statistics for selected variables was done. The findings in Table 3 confirmed that the average and standard deviation of the variables were in the minimum and maximum interval. Therefore, the highest average value of GHG was for the Czech Republic (2.61) and Poland (2.36); at the same time, the lowest level was for Hungary (1.92). The most variables were negatively skewed (63\%), while only $37 \%$ were positively skewed. In particular, the logarithm of GHG (for all countries), GDP 
(for all countries), PA (for the Czech Republic, Hungary, Slovak Republic) and Inv (for all countries) were negatively skewed. It means that the average value could not describe a real picture of the country's development. Besides, all variables had a positive level of kurtosis, which confirmed that the variables analysed were possibly leptokurtic in form.

Table 3. Descriptive statistics for GHG, GDP, RD, PA, Inv, FDI, HC.

\begin{tabular}{|c|c|c|c|c|c|c|c|c|c|}
\hline Variable & Country & Mean & Maximum & Minimum & Std. Dev. & Skewness & Kurtosis & Jarque-Bera & Probability \\
\hline \multirow{4}{*}{$\ln G H G$} & 1 & 2.61 & 2.70 & 2.50 & 0.08 & -0.18 & 1.33 & 2.30 & 0.32 \\
\hline & 2 & 1.92 & 2.03 & 1.76 & 0.09 & -0.21 & 1.68 & 1.51 & 0.47 \\
\hline & 3 & 2.36 & 2.40 & 2.31 & 0.03 & -0.16 & 1.89 & 1.06 & 0.59 \\
\hline & 4 & 2.16 & 2.26 & 2.03 & 0.09 & -0.16 & 1.40 & 2.10 & 0.35 \\
\hline \multirow{4}{*}{$\operatorname{lnGDP}$} & 1 & 12.87 & 13.07 & 12.62 & 0.13 & -0.54 & 2.25 & 1.39 & 0.50 \\
\hline & 2 & 14.98 & 15.20 & 14.74 & 0.12 & -0.25 & 2.85 & 0.21 & 0.90 \\
\hline & 3 & 10.48 & 10.83 & 10.15 & 0.22 & -0.13 & 1.75 & 1.30 & 0.52 \\
\hline & 4 & 9.39 & 9.68 & 8.99 & 0.22 & -0.53 & 1.95 & 1.78 & 0.41 \\
\hline \multirow{4}{*}{$\ln R D$} & 1 & 0.35 & 0.68 & 0.10 & 0.22 & 0.30 & 1.42 & 2.25 & 0.32 \\
\hline & 2 & 0.09 & 0.44 & -0.24 & 0.19 & 0.09 & 1.85 & 1.08 & 0.58 \\
\hline & 3 & -0.32 & 0.19 & -0.62 & 0.26 & 0.46 & 1.82 & 1.78 & 0.41 \\
\hline & 4 & -0.44 & 0.16 & -0.80 & 0.28 & 0.39 & 2.17 & 1.02 & 0.60 \\
\hline \multirow{5}{*}{$\ln P A$} & 1 & 6.58 & 6.89 & 6.27 & 0.19 & -0.09 & 1.84 & 1.09 & 0.58 \\
\hline & 2 & 6.50 & 6.82 & 6.01 & 0.19 & -0.85 & 3.79 & 2.77 & 0.25 \\
\hline & 3 & 8.02 & 8.45 & 7.61 & 0.30 & 0.11 & 1.31 & 2.31 & 0.32 \\
\hline & 4 & 5.33 & 5.56 & 5.04 & 0.15 & -0.43 & 2.06 & 1.28 & 0.53 \\
\hline & 1 & 3.88 & 4.39 & 2.28 & 0.61 & -1.39 & 3.96 & 6.87 & 0.03 \\
\hline \multirow{3}{*}{$\ln I n v$} & 2 & 3.80 & 4.37 & 1.95 & 0.70 & -1.33 & 3.67 & 5.92 & 0.05 \\
\hline & 3 & 3.75 & 4.35 & 1.99 & 0.68 & -1.50 & 4.22 & 8.30 & 0.02 \\
\hline & 4 & 4.00 & 4.40 & 2.24 & 0.61 & -2.07 & 6.13 & 21.34 & 0.00 \\
\hline \multirow{4}{*}{$\ln \mathrm{HC}$} & 1 & 4.27 & 4.34 & 4.24 & 0.03 & 1.05 & 2.66 & 3.58 & 0.17 \\
\hline & 2 & 4.15 & 4.28 & 4.08 & 0.06 & 0.92 & 2.44 & 2.91 & 0.23 \\
\hline & 3 & 4.19 & 4.25 & 4.15 & 0.03 & 0.58 & 2.05 & 1.78 & 0.41 \\
\hline & 4 & 4.25 & 4.28 & 4.22 & 0.02 & 0.84 & 2.65 & 2.32 & 0.31 \\
\hline
\end{tabular}

Note: 1-Czech Republic; 2-Hungary; 3-Poland; 4-Slovak Republic.

The next step was to check the data for stationarity using the ADF-statistic and PhillipsPerron tests. The findings of ADF-statistic and Phillips-Perron tests are in Table 4. The empirical results and critical value of $t$-statistics for variables GHG, GDP, RD, PA and HC were less than the absolute value of thresholds at $1 \%, 5 \%$ and $10 \%$ significance levels. Additionally, $p$-value (probability) of the tests were in average $0.744(74.4 \%$, that is $p$-value $>10 \%$ ). Therefore, as the minimum probability of existing the unit root in data and the time series-not stationary was $75 \%$ ( $p$-value $>10 \%)$, the hypothesis on existing of a unit root in time series could not be rejected. The findings confirmed the stationarity of series for the Czech Republic, Hungary and Poland at a level only for the variable Inv. The results of Dicky-Fuller and Phillips-Perron tests for time series at the first differences confirmed the stationarity of the modified data. The absolute value of $\mathrm{t}$-statistic was less than the absolute value of thresholds at $1 \%, 5 \%$ and $10 \%$ significance levels. Moreover, the $p$-value (probability) was $0.000(0 \%$, that is $p$-value $<10 \%)$. The findings allowed rejecting the null hypothesis-existing of a unit root in the first differences of the time series with minimum probability (in almost $0 \%$ of cases out of $100 \%$ ). Therefore, the time series in the first differences were stationary, and the series at level had the order of integration 1. 
Table 4. Findings of ADF-Statistic and Phillips-Perron tests (Source: developed by the author).

\begin{tabular}{|c|c|c|c|c|c|c|c|c|c|}
\hline \multirow{2}{*}{\multicolumn{2}{|c|}{ Variable }} & \multicolumn{4}{|c|}{ ADF-Statistic } & \multicolumn{4}{|c|}{ Phillips-Perron } \\
\hline & & 1 & 2 & 3 & 4 & 1 & 2 & 3 & 4 \\
\hline \multicolumn{10}{|c|}{ At Level } \\
\hline \multirow{2}{*}{$\ln G H G$} & Value & -0.236 & -0.921 & -2.040 & -0.640 & -0.186 & -1.062 & -2.025 & -0.627 \\
\hline & Prob & 0.917 & 0.757 & 0.269 & 0.838 & 0.924 & 0.707 & 0.275 & 0.841 \\
\hline \multirow{2}{*}{$\operatorname{lnGDP}$} & Value & -1.313 & -0.903 & 0.273 & -1.677 & -1.263 & -0.990 & 0.180 & -1.780 \\
\hline & Prob & 0.600 & 0.763 & 0.970 & 0.425 & 0.623 & 0.733 & 0.963 & 0.378 \\
\hline \multirow{2}{*}{$\ln R D$} & Value & -0.334 & -0.784 & 1.325 & -2.949 & -0.334 & -0.471 & 1.163 & -0.954 \\
\hline & Prob & 0.901 & 0.799 & 0.998 & 0.063 & 0.901 & 0.876 & 0.996 & 0.746 \\
\hline \multirow{2}{*}{$\ln \mathrm{PA}$} & Value & -1.551 & 0.895 & -0.493 & -3.807 & -1.517 & 2.696 & -0.493 & -4.250 \\
\hline & Prob & 0.486 & 0.992 & 0.871 & 0.012 & 0.503 & 1.000 & 0.871 & 0.005 \\
\hline \multirow{2}{*}{$\ln \operatorname{Inv}$} & Value & -3.995 & -5.453 & -6.072 & -2.239 & -20.68 & -13.77 & -12.09 & -11.38 \\
\hline & Prob & 0.009 & 0.001 & 0.000 & 0.202 & 0.000 & 0.000 & 0.000 & 0.000 \\
\hline \multirow{2}{*}{$\ln \mathrm{HC}$} & Value & -0.628 & 2.214 & 1.204 & 0.449 & 1.544 & 1.817 & 1.023 & 0.222 \\
\hline & Prob & 0.836 & 1.000 & 0.997 & 0.979 & 0.999 & 0.999 & 0.995 & 0.966 \\
\hline \multicolumn{10}{|c|}{ At 1st Difference } \\
\hline \multirow{2}{*}{$\ln G H G$} & Value & -3.464 & -3.449 & -4.338 & -5.092 & -3.551 & -3.455 & -4.451 & -4.968 \\
\hline & Prob & 0.024 & 0.024 & 0.004 & 0.001 & 0.019 & 0.023 & 0.003 & 0.001 \\
\hline \multirow{2}{*}{$\operatorname{lnGDP}$} & Value & -4.651 & -5.809 & -4.829 & -3.208 & -5.483 & -6.083 & -5.798 & -3.217 \\
\hline & Prob & 0.003 & 0.000 & 0.002 & 0.037 & 0.001 & 0.000 & 0.000 & 0.037 \\
\hline \multirow{2}{*}{$\ln R D$} & Value & -2.912 & -3.770 & -4.706 & -4.971 & -2.931 & -4.438 & -9.381 & -4.893 \\
\hline & Prob & 0.065 & 0.013 & 0.003 & 0.001 & 0.063 & 0.003 & 0.000 & 0.001 \\
\hline \multirow{2}{*}{$\operatorname{lnPA}$} & Value & -4.005 & -4.925 & -3.934 & -5.853 & -4.004 & -5.066 & -3.934 & -6.945 \\
\hline & Prob & 0.008 & 0.002 & 0.009 & 0.000 & 0.008 & 0.001 & 0.009 & 0.000 \\
\hline \multirow{2}{*}{$\operatorname{lnInv}$} & Value & -8.948 & -12.14 & -11.87 & -3.267 & -6.055 & -4.810 & -9.659 & -3.208 \\
\hline & Prob & 0.000 & 0.000 & 0.000 & 0.033 & 0.000 & 0.002 & 0.000 & 0.037 \\
\hline \multirow{2}{*}{$\operatorname{lnHC}$} & Value & -5.287 & -6.393 & -7.151 & -3.693 & -6.021 & -6.440 & -14.78 & -3.760 \\
\hline & Prob & 0.001 & 0.000 & 0.000 & 0.015 & 0.000 & 0.000 & 0.000 & 0.013 \\
\hline
\end{tabular}

Note: 1-Czech Republic; 2-Hungary; 3-Poland; 4-Slovak Republic.

The findings of the selected variables' impact on GHG emissions are in Table 5. The empirical results confirmed that increasing the research and development expenditure stimulates the decline of greenhouse gas emission as for each and all the Visegrád countries. Thus, the results of FMOSL test allowed identifying the negative relation among RD, PA and GHG emissions at a value of $1 \%$. This means that increasing research and development expenditure by $1 \%$ leads to a $0.25 \%$ decline of GHG emissions, while the increase of patent applications by $1 \%$ provokes a $0.14 \%$ decrease of GHG emissions. In addition, an increase in the number of individuals using the internet by $1 \%$ leads to a $0.05 \%$ reduction of GHG emissions. According to panel DOLS results, a 1\% increase of RD, PA, Inv resulted in decreases of GHG emissions by $0.24 \%, 0.1 \%$ and $0.02 \%$, respectively.

It should be noted that in the model without control variables, the variables RD and PA for the Czech Republic had the most statistically significant impact on the decline of GHG emissions. Thus, a 1\% increase of RD and PA leads to a decline of GHG emissions of $0.53 \%$ and $0.457 \%$, respectively. At the same time, in the model with control variables, the indicator RD had a statistically significant impact at the level of $1 \%$. A $1 \%$ increase of RD resulted in a $0.35 \%$ decline in GHG emissions.

The findings allow the conclusion that the impact of Inv on GHG emissions at the level of $10 \%$ was only for Hungary and Poland in the model with control variables. In Poland, the increase of the variable 'individuals using the Internet' at a 1\% level led to a decline of GHG emissions of $0.04 \%$. 
Table 5. Results of analysing the impact of the selected variables on GHG emissions (Source: developed by the author).

\begin{tabular}{|c|c|c|c|c|c|c|c|c|}
\hline \multirow{3}{*}{ Variable } & \multicolumn{8}{|c|}{ Static } \\
\hline & \multicolumn{4}{|c|}{ Without Control Variables } & \multicolumn{4}{|c|}{ With Control Variables } \\
\hline & 1 & 2 & 3 & 4 & 1 & 2 & 3 & 4 \\
\hline \multirow{2}{*}{$\ln R D$} & -0.537 & -0.255 & -0.290 & -0.298 & -0.347 & -0.409 & -0.113 & -0.227 \\
\hline & $(0.000)^{* * *}$ & 0.124 & $(0.000)^{* * *}$ & $(0.000)^{* * *}$ & $(0.000)^{* * *}$ & $(0.008)^{* * *}$ & $(0.007)^{* * *}$ & $(0.000)^{* * *}$ \\
\hline \multirow{2}{*}{$\ln P A$} & -0.457 & -0.281 & -0.280 & -0.381 & 0.029 & -0.218 & -0.069 & -0.003 \\
\hline & $(0.000)^{* * *}$ & $(0.000)^{* * *}$ & $(0.000)^{* * *}$ & $(0.000)^{* * *}$ & 0.680 & $(0.028)^{* *}$ & 0.119 & 0.953 \\
\hline \multirow{2}{*}{$\ln \operatorname{Inv}$} & -0.053 & 0.029 & 0.006 & 0.001 & -0.067 & -0.062 & -0.046 & -0.004 \\
\hline & 0.153 & 0.470 & 0.782 & 0.984 & 0.106 & $(0.078) *$ & $(0.063) *$ & 0.873 \\
\hline \multirow{2}{*}{$\ln \mathrm{HC}$} & - & - & - & $\ldots$ & -0.378 & -0.738 & -0.350 & 0.909 \\
\hline & - & - & - & - & 0.410 & 0.176 & 0.211 & $(0.000) * * *$ \\
\hline $\operatorname{lnGDP}$ & - & - & - & & 0.343 & 0.446 & 0.431 & -0.188 \\
\hline IIIUDF & - & - & - & - & $(0.056) *$ & $(0.022) * *$ & $(0.002)^{* * *}$ & $(0.033) * *$ \\
\hline R-squared & 0.590 & 0.432 & 0.563 & 0.539 & 0.626 & 0.894 & 0.842 & 0.626 \\
\hline
\end{tabular}

Panel Results

\begin{tabular}{|c|c|c|c|c|}
\hline \multirow{3}{*}{$\operatorname{lnRD}$} & \multicolumn{2}{|c|}{ FMOLS } & \multicolumn{2}{|c|}{ DOLS } \\
\hline & -0.253827 & -0.34701 & -0.239 & -0.320 \\
\hline & $(0.000)^{* * *}$ & $(0.000)^{* * *}$ & $(0.000) * * *$ & $(0.000) * * *$ \\
\hline \multirow{2}{*}{$\ln P A$} & -0.149868 & -0.184359 & -0.103 & -0.131 \\
\hline & $(0.000)^{* * *}$ & $(0.000)^{* * *}$ & $(0.017)^{* *}$ & $(0.004) * * *$ \\
\hline \multirow{2}{*}{$\operatorname{lnInv}$} & -0.016609 & -0.051 & -0.024 & -0.041 \\
\hline & 0.4312 & $(0.0415)^{* *}$ & $(0.097) *$ & $(0.065) *$ \\
\hline \multirow{2}{*}{$\operatorname{lnHC}$} & & 0.0393 & 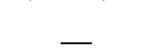 & 0.381 \\
\hline & - & 0.108 & - & 0.225 \\
\hline \multirow{2}{*}{$\operatorname{lnGDP}$} & & 0.148959 & & 0.130 \\
\hline & - & 0.1033 & - & 0.176 \\
\hline R-squared & 0.968047 & 0.6324 & 0.968 & 0.972 \\
\hline
\end{tabular}

Note: 1 -Czech Republic; 2-Hungary; 3-Poland; 4-Slovak Republic; ${ }^{*}{ }^{* *},{ }^{* * *}$ represents significance at the $1 \%, 5 \%$ and $10 \%$ levels.

\section{Conclusions}

The Green Deal Policy is aimed at mobilizing the research and fostering innovations on decarbonizing the economy for future sustainable development. Considering "Just Transition Mechanism", all EU members should be involved in achieving the climateneutral economy. Besides, the most affected regions where coal is a key resource (such as Poland and the Czech Republic) should reorient their internal policy and invest more in innovative technologies which allow replacing coal with a climate-neutral resource and reducing GHG emissions. The achievement of that goal requires supporting the innovation development of the industry, decarbonizing the energy sector and investing in green technologies. Thus, the "Initiative for Coal Regions in Transition" focused on spreading the most effective green technologies among the EU coal regions by developing the stakeholders' network and providing financial resources for green innovations.

The results of the analysis show the GDP effect on GHG, which is similar with conclusions in other papers (Arshad et al. 2020; Bilan et al. 2019; Miskiewicz 2020b; Prokopenko and Miśkiewicz 2020; Vasylieva et al. 2019). Additionally, developing informational and innovation technologies had a statistically significant impact on GHG emissions. Considering the findings in the models without control variables, increasing patents by $1 \%$ leads to reducing GHG emissions by $0.28 \%$ for Poland, $0.28 \%$ for Hungary, $0.38 \%$ for the Slovak Republic and $0.46 \%$ for the Czech Republic. At the same time, for the models with control variables, the statistically significant impact was only for Hungary. Thus, increasing patents by $1 \%$ led to reducing GHG emissions by $0.22 \%$. The variable R\&D expenditure was statistically significant for all countries and all types of models (with and without control variables). The increase of R\&D expenditure resulted in a decline of GHG emissions by $0.29 \%$ (without control variables) and $0.11 \%$ (with control variables) for Poland, by 
$0.26 \%$ (without control variables) and $0.41 \%$ (with control variables) for Hungary, by $0.3 \%$ (without control variables) and $0.23 \%$ (with control variables) for the Slovak Republic and by $0.54 \%$ (without control variables) and $0.38 \%$ (with control variables) for the Czech Republic. At the same time, the findings proved that, for the Visegrád countries, a percentage of the individuals using the Internet did not influence the GHG emissions, excluding two cases of Hungary and Poland for the models with control variables. There were findings opposite to the conclusions in the papers Nair et al. (2020) and Majeed and Ayub (2018). This means that the Czech Republic and the Slovak Republic should focus on developing innovative technologies in the energy and industrial sectors.

The EU "Energy Transition Package" is aimed to support the less developed EU members and to assist them on the way to the reorientation of the national energy system. Poland has already attracted more than 205 million EUR from the European Investment Bank for the transition to a low-carbon economy. The European Investment Bank declared they were going to finance up to $75 \%$ of the project cost aimed to increase energy efficiency, extending renewable energies in 10 countries: the Czech Republic, Slovakia, Hungary, Poland, Romania, Bulgaria, Latvia, Croatia, Lithuania and Estonia.

The results of this analysis show that the EU developed a range of mechanisms to support the transition to the carbon-free economy. In this case, the Visegrád countries should integrate their home policy using the supportive options from the European Commission with the purpose of achieving the goals of a carbon-free economy. At the same time, the EU should consider the fact that, for the selected countries, the most effective instruments are green innovative technologies.

Funding: This research received no external funding.

Conflicts of Interest: The author declares no conflict of interest.

\section{References}

Akimova, Luidmyla, Oleksandr Akimov, and Olga Liakhovich. 2017. State Regulation of Foreign Economic Activity. Scientific Bulletin of Polissia 4: 98-103. [CrossRef]

Arshad, Zeeshan, Margarita Robaina, and Anabela Botelho. 2020. The Role of ICT in Energy Consumption and Environment: An Empirical Investigation of Asian Economies with Cluster Analysis. Environmental Science and Pollution Research 27: $32913-32$. [CrossRef] [PubMed]

Asongu, Simplice A., and Nicholas M. Odhiambo. 2019. Foreign Direct Investment, Information Technology and Economic Growth Dynamics in Sub-Saharan Africa. Telecommunications Policy 44: 101838. [CrossRef]

Bogachov, Sergii, Aleksy Kwilinski, Boris Miethlich, Viera Bartosova, and Aleksandr Gurnak. 2020. Artificial Intelligence Components and Fuzzy Regulators in Entrepreneurship Development. Entrepreneurship and Sustainability Issues 8: 487-99. [CrossRef]

Bilan, Yurii, Dalia Streimikiene, Tetyana Vasylieva, Oleksii Lyulyov, Tetyana Pimonenko, and Anotolii Pavlyk. 2019. Linking Between Renewable Energy, $\mathrm{CO}_{2}$ Emissions, and Economic Growth: Challenges for Candidates and Potential Candidates for the EU Membership. Sustainability 11: 1528. [CrossRef]

Chimbo, Bester. 2020. Energy Consumption, Information and Communication Technology and Economic Growth in an African Context. International Journal of Energy Economics and Policy 10: 486-93. [CrossRef]

Chygryn, Olena, Yurii Bilan, and Aleksy Kwilinski. 2020. Stakeholders of Green Competitiveness: Innovative Approaches for Creating Communicative System. Marketing and Management of Innovations 3: 356-68. [CrossRef]

Dementyev, Vyacheslav V., and Aleksy Kwilinski. 2020. Institutional Component of Production Costs. Journal of Institutional Studies 12: 100-16. [CrossRef]

Dkhili, Hichem. 2018. Environmental Performance and Institutions Quality: Evidence from Developed and Developing Countries. Marketing and Management of Innovations 3: 333-44. [CrossRef]

Dzwigoł, Henryk, Mariola Dzwigoł-Barosz, Zinaida Zhyvko, Radosław Miskiewicz, and Halyna Pushak. 2019. Evaluation of the Energy Security as a Component of National Security of the Country. Journal of Security and Sustainability Issues 8: 307-17. [CrossRef]

Dzwigol, Henryk, Mariola Dzwigol-Barosz, Radosław Miskiewicz, and Aleksy Kwilinski. 2020. Manager Competency Assessment Model in the Conditions of Industry 4.0. Entrepreneurship and Sustainability Issues 7: 2630-44. [CrossRef]

Kendiukhov, Igor, and Manuela Tvaronavičienè. 2017. Managing Innovations in Sustainable Economic Growth. Marketing and Management of Innovations 3: 33-42. [CrossRef]

Khan, Farzana Naheed, Aiman Sana, and Umaima Arif. 2020. Information and Communication Technology (ICT) and Environmental Sustainability: A Panel Data Analysis. Environmental Science and Pollution Research 27: 36718-31. [CrossRef] [PubMed] 
Kharazishvili, Yurii, Aleksy Kwilinski, Olena Grishnova, and Henryk Dzwigol. 2020. Social Safety of Society for Developing Countries to Meet Sustainable Development Standards: Indicators, Level, Strategic Benchmarks (with Calculations Based on the Case Study of Ukraine). Sustainability 12: 8953. [CrossRef]

Kuzior, Aleksandra, Aleksy Kwilinski, and Volodymyr Tkachenko. 2019. Sustainable Development of Organizations Based on the Combinatorial Model of Artificial Intelligence. Entrepreneurship and Sustainability 7: 1353-76. [CrossRef]

Kuznets, Simon. 1955. Economic Growth and Income Inequality. The American Economic Review 45: 1-28. Available online: https: //www.jstor.org/stable/1811581 (accessed on 9 September 2020).

Kwilinski, Aleksy. 2018a. Mechanism of Modernization of Industrial Sphere of Industrial Enterprise in Accordance with Requirements of the Information Economy. Marketing and Management of Innovations 4: 116-28. [CrossRef]

Kwilinski, Aleksy. 2018b. Mechanism of Formation of Industrial Enterprise Development Strategy in the Information Economy. Virtual Economics 1: 7-25. [CrossRef]

Kwilinski, Aleksy, Volodymyr Tkachenko, and Aleksandra Kuzior. 2019. Transparent Cognitive Technologies to Ensure Sustainable Society Development. Journal of Security and Sustainability 9: 561-70. [CrossRef]

Kwilinski, Aleksy, and Aleksandra Kuzior. 2020. Cognitive Technologies in the Management and Formation of Directions of the Priority Development of Industrial Enterprises. Management Systems in Production Engineering 28: 119-23. [CrossRef]

Kwilinski, Aleksy, Yulia Zaloznova, Natalia Trushkina, and Natalia Rynkevych. 2020a. Organizational and Methodological Support for Ukrainian Coal Enterprises Marketing Activity Improvement. E3S Web of Conferences 168: 00031. [CrossRef]

Kwilinski, Aleksy, Oleksandr Vyshnevskyi, and Henryk Dzwigol. 2020b. Digitalization of the EU Economies and People at Risk of Poverty or Social Exclusion. Journal of Risk and Financial Management 13: 142. [CrossRef]

Lange, Stephan, Johanna Pohl, and Tilman Santarius. 2020. Digitalization and Energy Consumption. Does ICT Reduce Energy Demand? Ecological Economics 176: 106760. [CrossRef]

Lyulyov, Oleksii, and Tetyana Pimonenko. 2017. Lotka-Volterra Model as an Instrument of the Investment and Innovative Processes Stability Analysis. Marketing and Management of Innovations 3: 159-69. [CrossRef]

Majeed, Muhammad Tariq, and Tayba Ayub. 2018. Information and Communication Technology (ICT) and Economic Growth Nexus: A Comparative Global Analysis. Pakistan Journal of Commerce and Social Sciences 12: 443-76.

Mazurkiewicz, Joanna, and Piotr Lis. 2018. Diversification of Energy Poverty in Central and Eastern European Countries. Virtual Economics 1: 26-41. [CrossRef]

Miskiewicz, Radoslaw. 2018. The Importance of Knowledge Transfer on the Energy Market. Polityka Energetyczna 21: 49-62. [CrossRef]

Miskiewicz, Radoslaw. 2019a. Challenges Facing Management Practice in the Light of Industry 4.0: The Example of Poland. Virtual Economics 2: 37-47. [CrossRef]

Miskiewicz, Julia. 2019b. The Merger of Natural Intelligence with Artificial Intelligence, with a Focus on Neuralink Company. Virtual Economics 2: 22-29. [CrossRef]

Miskiewicz, Radoslaw. 2020a. Internet of Things in Marketing: Bibliometric Analysis. Marketing and Management of Innovations 3: 371-81. [CrossRef]

Miskiewicz, Radoslaw. 2020b. Efficiency of Electricity Production Technology from Post-Process Gas Heat: Ecological, Economic and Social Benefits. Energies 13: 6106. [CrossRef]

Miśkiewicz, Radoslaw, and Radoslaw Wolniak. 2020. Practical Application of the Industry 4.0 Concept in a Steel Company. Sustainability 12: 5776. [CrossRef]

Nair, Mahendhiran, Rudra P. Pradhan, and Mak B. Arvin. 2020. Endogenous Dynamics between R\&D, ICT and Economic Growth: Empirical Evidence from the OECD Countries. Technology in Society 62: 101315. [CrossRef]

Pajak, Kazimierz, Oleksii Kvilinskyi, Olga Fasiecka, and Radosław Miśkiewicz. 2017. Energy Security in Regional Policy in Wielkopolska Region of Poland. Economics and Environment 2: 122-38. Available online: https://www.ekonomiaisrodowisko.pl/uploads / eis\%2061/11_pajak.pdf (accessed on 9 September 2020).

Prokopenko, Olha, and Radosław Miśkiewicz. 2020. Perception of "Green Shipping" in the Contemporary Conditions. Entrepreneurship and Sustainability Issues 8: 269-84. [CrossRef]

Raheem, Ibrahim D., Aviral Kumar Tiwari, and Daniel Balsalobre-Lorente. 2020. The Role of ICT and Financial Development in $\mathrm{CO}_{2}$ Emissions and Economic Growth. Environmental Science and Pollution Research 27: 1912-22. [CrossRef]

Saługa, Piotr W., Katarzyna Szczepańska-Woszczyna, Radosław Miśkiewicz, and Mateusz Chłąd. 2020. Cost of Equity of Coal-Fired Power Generation Projects in Poland: Its Importance for the Management of Decision-Making Process. Energies 13: 4833. [CrossRef]

Siddiqui, Areej Aftab, and Parul Singh. 2020. ICT Penetration and Economic Growth: An Empirical Analysis of Major Trading Nations. The Indian Economic Journal 67: 312-33. [CrossRef]

Tsaurai, Kunofiwa. 2020. Information and Communication Technology, Energy Consumption and Financial Development in Africa. International Journal of Energy Economics and Policy 10: 429-37. [CrossRef]

Vasylieva, Tetyana, Oleksii Lyulyov, Yurii Bilan, and Dalia Streimikiene. 2019. Sustainable Economic Development and Greenhouse Gas Emissions: The Dynamic Impact of Renewable Energy Consumption, GDP, and Corruption. Energies 12: 3289. [CrossRef]

Zahorskyi, Volodymyr, Andriy Lipentsev, Natalia Yurystovska, and Oleksandr Akimov. 2019. Financial and Administrative Aspects of Small Business Development in Ukraine. Financial and Credit Activity: Problems of Theory and Practice 3: 351-60. [CrossRef] 